$\S=-1$

\title{
Effectiveness Model of Village Funds to Measure Village Per- formance Through Economic Empowerment towards Prospeous Communities in East Java Coastal Areas
}

\author{
Ratna Ekasari $^{1 *}$, Tri Ratnawati², Sigit Sardjono ${ }^{3}$ \\ ${ }^{1}$ Faculty of Economic, Universitas Maarif Hasyim Latif, Sidoarjo, Indonesia \\ ${ }^{2}$ Faculty of Economic, Universitas 17 Agustus 1945 Surabaya, Surabaya, Indonesia \\ *Corresponding author E-mail: ratna_ekasari@dosen.umaha.ac.id
}

\begin{abstract}
Rural communities that are part of the unitary state of the Republic of Indonesia need attention and the role of the government to improve the lives of its citizens to achieve a just and prosperous society according to the mandate of the Constitution. For this reason, the use of village funds which is a manifestation of government assistance for equitable development must be formulated and managed appropriately, transparently and accountable. This research method with a population of six villages in the coastal areas of East Java carried out by collecting data quantitatively namely the factual management of village funds based on histories from four research objects, which were analyzed based on the formulation of budget effectiveness. While the data obtained qualitatively obtained by questionnaires and interviews with respondents of the object of research, which is then analyzed to obtain the influence of independent variables on the dependent variable using the IBM SPSS Statistics software Ver.20. The results show that: quantitatively village budget management can be said to have effective assessment criteria, which is indicated by the percentage value above the specified effectiveness threshold. Whereas qualitatively it was found that the Village Fund variable did not show a positive and significant effect on the variables of budget effectiveness. Village Program variables do not show a positive and significant impact on the variable effectiveness of the budget. The Program Urgency variable does not show a positive and significant impact on budget effectiveness variables. The Program Implementation variable shows a positive and significant effect on the variable of budget effectiveness. Monitoring and Reporting variables show a positive and significant influence on budget effectiveness variables. Furthermore, the Budget Effectiveness Model is formulated which will be used as a reference in using village funds for the development and welfare of coastal communities in East Java.
\end{abstract}

Keywords: Village Fund Management, Village Program, Program Urgency, Program Implementation, Monitoring, and Reporting, Budget Effectiveness Model

\section{Introduction}

The achievement of a prosperous, just and prosperous Indonesian society is the mandate of the Law which is a manifestation of the noble ideals of the founders of the Indonesian nation [1], [2]. The existence of social inequality in the life between our layers of society is a real phenomenon that is still a homework that must be resolved by the government together with all active participation of Indonesian citizens so that the ideals of the law can be realized [3]-[5]. Part of the community that still does not achieve a prosperous standard of living according to the mandate of the law is the rural community. For this reason, the government gives full attention to improving the development of rural communities to achieve a prosperous life. Through Government Regulation Number 60 of 2014 concerning the village funds budget, the government seeks to provide subsidies to village governments to be able to carry out the role of the village administration by empowering and maximizing the management of the village's potential by the village's vision and mission [6]-[9]. The control of the village budget that has been given to the village government taken from the Regional Budget as known as APBD is expected to be carried out in a transparent and accountable manner. To have an impact on improving the standard of living of the villagers according to the village's potential and ability to develop it. Thus, there is a need for appropriate governance and model to use the village budget effectively, which has an impact on improving village performance, so that community economic empowerment is expected to be achieved as a prosperous society [9].

\section{Method}

\subsection{Data}

This study uses primary data and secondary data. Secondary data is obtained from the historical information of the village government in using village funds for various village programs carried out in rural development. Secondary data processing with the formulation of the effectiveness of the use of the budget that produces a percentage of the budget. Furthermore, to determine the priority criteria for superior villages according to core competence from each village, a Potential Village will be obtained to be developed as a pilot project, with the Analytical Hierarchy Process (AHP) Method. Primary data is obtained from respondents' answers to questionnaire questions, from the population of the coastal village apparatus in East Java with saturated sampling 
method, which uses all communities as research samples [10], $\mathrm{s}[11]$.

\subsection{Variable}

In this study using two types of variables, the dependent variable and the independent variable. Independent Variable Consists of Village Fund variables (X1), Village Programs (X2), Program Urgency (X3), Program Implementation (X4) and Monitoring \& Reporting (X5), with each item question with 1-5 Likert scale answers which states the situation is Strongly Disagree, Disagree, Agree, Strongly Agree and Absolute Agree [12]. Dependent variables are budget effectiveness variables (Y), with 6 question items with 1-5 Likert scale answers which states the situation is Strongly Disagree, Disagree, Agree, Strongly Agree and Absolute Agree [12].

\subsection{Conceptual Framework}

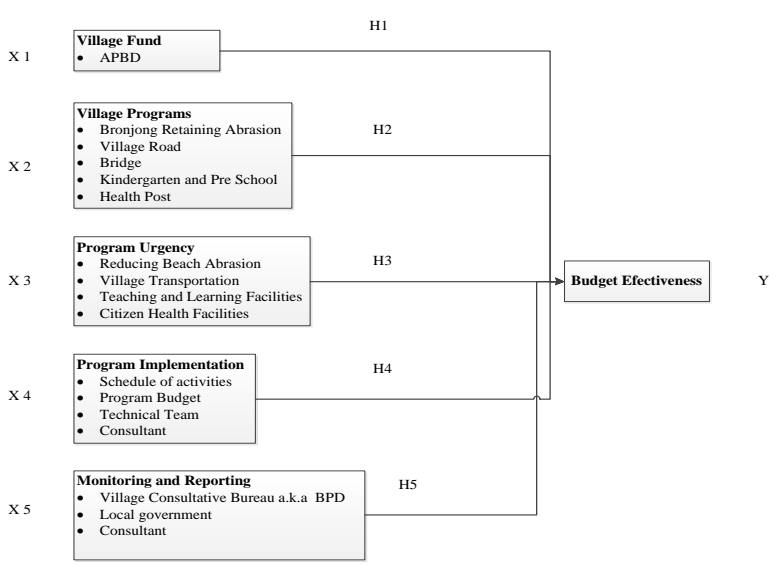

Fig. 1. Variables relationship framework

\subsection{Data Analysis}

In the data analysis stage, the first is to test the data quality using reliability test and validity test. With a construct or variable said to be reliable if it has a Cronbach alpha value > 0.60. Then test hypotheses on five hypotheses that have been determined. in the next stage, test with correlation coefficient test, Multiple Linear regression analysis and Regression Equation Test.

\section{Result And Discussion}

\subsection{Quantitative Analysis using Analytical Hierarchy Process}

Form the six research villages; one village was chosen as the pilot village to analyze the potential. By using the AHP (Analytical Hierarchy Process) method which is one of the analytical tools that work structurally based on the value of the comparison between the criteria characteristics and criteria of the research object. With the step "pairwise comparison" or Pairwise Comparison, from the variables, studied, namely: Potential Village, Number of Population, Area Size, Problems faced, Source of Funds, Role of Government, and Participation of Villagers, obtained criteria values such as table 1 .

Table 1. Criteria Analysis Matrix on Each Research Object

\begin{tabular}{|l|l|l|l|l|l|l|l|l|}
\hline Criteria & Potential Village & Total Population & An Area & Problem & Fundraising & Government Role & Citizen Participation & Total \\
\hline Village 1 & 0.12 & 0.03 & 0.08 & 0.15 & 0.42 & 0.05 & 0.15 & 1.00 \\
\hline Village 2 & 0.19 & 0.05 & 0.01 & 0.54 & 0.42 & 0.01 & 0.53 & \\
\hline Village 3 & 2.30 & 0.01 & 0.14 & 1.57 & 0.42 & 0.01 & 0.53 & \\
\hline Village 4 & 0.40 & 0.01 & 0.01 & 1.57 & 1.09 & 0.00 & 0.53 \\
\hline Village 5 & 0.73 & 0.13 & 0.04 & 0.33 & 1.54 & 0.01 & 0.53 \\
\hline Village 6 & 1.03 & 0.03 & 0.27 & 0.80 & 0.42 & 0.00 & 2.19 & \\
\hline
\end{tabular}

From the stages of the AHP method process, the final assessment criteria are obtained as presented in the table above. From the results of the AHP analysis, it was found that village 3 or Coastal Village obtained the highest score criteria of 5.00 compared to other communities as the object of research. So that the Coastal Village (Gending) with all the available potential. Then used as a pilot object to be analyzed in this research.

\subsection{Budget Effectiveness Analysis}

$$
\text { Effectivity }=\frac{\text { Realization of program funds }}{\text { Village Funds }}=\frac{\text { Rp. } 746.084 .483}{\text { Rp. 782.664.239 }}=95.33 \%
$$

Based on the value of the effectiveness ratio, the percentage of effectiveness of Coastal Village (Gending) effectiveness is at the "effective" interval, so it can be concluded that the use of village funds has proven effective.

\subsection{Qualitative Analysis}

Through the Pearson correlation test, the calculated R-value will be obtained. With the number of respondents 139 , the degree of freedom $=139-2=137$ and the significance level of
Furthermore, it will be known how effective the Coastal Village (Gending) is in using the Village Fund budget to implement the village development program. From the Village Fund budget owned by Pesisir Gending Village, Rp.782.664.239. Realization of the use of funds for village programs as prominent as Rp.746.084.483. So that the following formula can know the effectiveness of the budget managed by the Coastal Village (Gending):

$5 \%$. Then the $r$ table value is 0.167 . The calculated $r$ value will be compared to the $r$ table value. If the calculated $r$-value is higher than the $r$ table value, then it is said to be valid. Validity testing in this study has results which state that the variables have a value greater than 0.167 and declared valid. Furthermore, reliability testing shows that all values of Cronbach's alpha are above 0.7 so that it can be said that the respondent's response to the statement items is consistent over time. 


\subsection{Hypothesis testing}

Hypothesis testing is carried out simultaneously, that is, together or the entire independent variable is related to its influence on the dependent variable, as well as partial testing, i.e., individually each independent variable to the dependent variable

\subsection{Achievement of effectiveness}

Achievement of effectiveness for the village fund program implementation model can be shown in table 2 .

Table 2. Achievement of effectiveness

\begin{tabular}{|c|c|c|c|}
\hline No & Variables & Assesment Criteria & Achievement of effectiveness \\
\hline 1. & $\begin{array}{l}\text { Village Fund } \\
\text { (X1) }\end{array}$ & $\begin{array}{l}\text { Village funds that are available must support the achievement of } \\
\text { village priority programs. }\end{array}$ & The budget for each program is by its budget. \\
\hline 2. & $\begin{array}{l}\text { Village Program } \\
\text { (X2) }\end{array}$ & $\begin{array}{l}\text { The Village Program which is to be realized is a priority program } \\
\text { needed by the village program community is the result of the formu- } \\
\text { lation that has been prepared by the village government apparatus by } \\
\text { the Village Vision-Mission to create the welfare of its citizens. }\end{array}$ & $\begin{array}{l}\text { The Village Program that has been realized has a } \\
\text { direct impact on improving the economic life of the } \\
\text { community. }\end{array}$ \\
\hline 3. & $\begin{array}{l}\text { Program Urgency } \\
\text { (X3) }\end{array}$ & $\begin{array}{l}\text { The Village Program realized is an activity that has a priority scale } \\
\text { that is needed by the community. }\end{array}$ & $\begin{array}{l}\text { The Village Program that has been realized has a } \\
\text { direct impact on improving the economic life of the } \\
\text { community. }\end{array}$ \\
\hline 4. & $\begin{array}{l}\text { Program Imple- } \\
\text { mentation (X4) }\end{array}$ & $\begin{array}{l}\text { The Village Program realized has been carried out according to a } \\
\text { predetermined schedule. Village Programs are reallocated according } \\
\text { to the Village Program budget allocation that is realized is done by a } \\
\text { team of experts in their field involving consultants. }\end{array}$ & $\begin{array}{l}\text { The Village Program was realized according to the } \\
\text { schedule planned by the Village Program to be real- } \\
\text { ized by the budget allocation for the Village Program } \\
\text { budget that was realized and carried out by experts in } \\
\text { their fields. }\end{array}$ \\
\hline 5. & $\begin{array}{l}\text { Monitoring \& } \\
\text { Reporting (X5) }\end{array}$ & $\begin{array}{l}\text { Intensive monitoring and evaluation by related parties are carried } \\
\text { out during the implementation of the Village Program, to ensure that } \\
\text { the village program is carried out according to the Record plan. } \\
\text { Each activity on the village program is diligently carried out by the } \\
\text { implementing team, to prepare the Reporting when the village pro- } \\
\text { gram is completed. }\end{array}$ & $\begin{array}{l}\text { The monitoring and evaluation team intensively moni- } \\
\text { tors the implementation of the village program and } \\
\text { ensures the village program runs according to the } \\
\text { plan. Reporting must be made and submitted to the } \\
\text { relevant parties when the village program is complet- } \\
\text { ed. }\end{array}$ \\
\hline
\end{tabular}

\section{Conclusion}

Utilization of Village Funds by taking samples of Coastal Villages (Gending) as selected research objects with the AHP method, can be said to be effective with an efficiency ratio of $95.33 \%$. However, so that the use of village funds for other (village) objects can achieve budget effectiveness, it is necessary to create and apply a Budget Effectiveness Model that leads to a Performance-Based Budgeting Model, so that there is a reference and mechanism for using the budget for each priority activity program, to achieve effectiveness and efficiency of budget use.

Utilization of Village Funds with the application of the Village Performance-Based Budgeting Model is intended to empower the potential of the citizens of the coastal villages to be able to add the value of the natural potential produced which will undoubtedly increase the selling value that affects the community's economic growth. This is inseparable from the participation of relevant parties to support and assist the ability in the form of skills of coastal villagers in processing their natural products, with specific assistance or training. The application of the Village Performance Based Budgeting Model to utilize the existing Village Funds is expected to have an impact on the welfare of coastal village communities. With community empowerment evenly, it is expected that coastal villagers have independent income sources according to the skills they have in managing and processing the natural resources produced by their village, will improve the economy of the villagers which has an impact on the welfare of the villagers. PerformanceBased Budgeting Model in utilizing Village Funds for the achievement of coastal community welfare, through Performance-Based Budgeting Model variables include Village Fund to Village Program to Program Urgency to Program Implementation to Monitoring and Reporting, to fulfill Performance Evaluation Criteria for each variable.

\section{References}

[1] R. Indonesia, "Keputusan Menteri Dalam Negeri mendagri No. 690.900. 327 Tahun 1996 tentang Pedoman Penilaian Kinerja
Keuangan,” Jakarta Indones., 1996

[2] D. D. N. R. Indonesia, "Kepmendagri No. 690.900. 327. Pedoman Penilaian dan Kinerja Keuangan.” Jakarta: Depdagri, 1996.

[3] G. Kartasasmita, Pembangunan untuk rakyat: memadukan pertumbuhan dan pemerataan. Cides, 1996.

[4] J. Pramono, "Analisis Rasio Keuangan untuk Menilai Kinerja Keuangan Pemerintah Daerah (Studi Kasus pada Pemerintah Kota Surakarta)," J. Ilm. Among Makarti, vol. 7, no. 13, 2014.

[5] T. Riyanto, "Akuntabilitas Finansial Dalam Pengelolaan Alokasi Dana Desa (Add) di Kantor Desa Perangat Selatan Kecamatan Marangkayu Kabupaten Kutai Kartanegara," Ejournal Adm. Negara, vol. 3, no. 1, pp. 130-199, 2015.

[6] I. Bastian, "Akuntansi sektor publik," 2014.

[7] A. Subroto, "Akuntabilitas pengelolaan dana desa (studi kasus pengelolaan alokasi dana desa di desa-desa dalam wilayah Kecamatan Tlogomulyo Kabupaten Temanggung Tahun 2008)." UNIVERSITAS DIPONEGORO, 2009.

[8] S. Rasul, "Akuntabilitas Kinerja, Pengelolaan Keuangan Daerah Dalam Pelaksanaan Otonomi Daerah," J. Akunt., vol. 12, no. 3, pp. 324-338, 2008.

[9] M. Mahmudi, "New Public Management (NPM): Pendekatan Baru Manajemen Sektor Publik," Sinergi Kaji. Bisnis dan Manaj., vol. 6, no. 1, 2003.

[10] I. Ghozali, "Analisis Multivariate SPSS. Semarang: Badan Penerbit Universitas DiponegoroSunariyah. 2006. Pengantar Pengetahuan Pasar Modal.” Yogyakarta: UPP APP YKPN, 2011

[11] D. Bandung, "Metode Penelitian Pendidikan Pendekatan Kuantitatif, Kualitatif dan R \& D," Bandung Alf., 2013.

[12] P. Sugiyono, "Metode Penelitian Kuantitatif, Kualitatif, dan R\&D," Metod. Penelit. Kuantitatif, Kualitatif, dan R\&D. Bandung CV Alf., 2010. 